\title{
Determinants of Cash holding in German Market
}

\author{
Abbas Ali ${ }^{1}$, Samran Yousaf ${ }^{2}$ \\ ${ }^{1,2}$ Business Administration, University of Gujrat, Pakistan
}

\begin{abstract}
Cash is usually known as the blood of any business entity that is why it is very important policy matter in the modern corporate financial decision and policy matters. An appropriate level of cash is required within the firm for the good and smooth operations of any sort of business entity. This research report investigates the determinants of cash holding in non-financial firms of Germany across different firm sizes and industries. Furthermore the data set for the period of 2000 to 2010 for the firm size, log of total assets, EBIT, Capital expenditure percentage of sales, working capital, liquidity (current ratio), and leverage has been taken to study the impact of these on level of corporate cash holdings. It is shown that cash holdings must be analysed from a dynamic point of view: A strong empirical support was found for the hypothesis of implicit cash targets. Financial determinants influence the corporate cash holdings, but it's not clear which model, the transaction cost model or the managerial opportunism, thesis supports best the empirical findings. The findings of this study are consistent with the predictions of the trade-off theory, pecking order theory, and agency cost theory. The result gave strong evidence that firm size, working capital, and leverage significantly affect the cash holdings decisions of non-financial firms and that are in conformity with the existing literature on the determinants of corporate cash holdings.
\end{abstract}

Key words: Cash holdings, leverage, agency problems

\section{Introduction}

The corporate financial policies involve capital structure, working capital requirements, dividend payments, optimal level of cash holding and cash flow management and asset management. Corporate policies regarding cash and cash equivalents (marketable securities) have significant importance in the finance theory and applied corporate world. Cash and cash equivalent are considered to be one of the most important components of the current assets of the firm and are also called the life line of corporate financial management. The corporate cash holdings are usually determined and influenced by three important theories in corporate finance, that are trade off theory, pecking order theory and free cash flow theory.

Cash holdings has advantages and disadvantages as Well like cash is the most liquid asset that can be used any time to exploit any positive net present value project, on the other hand amount of cash holding reduce the transaction cost of the corporation. The proponent of trade off theory believe that firms while deciding level of cash holdings consider the marginal benefit and marginal cost (return foregone due to low return on liquid assets) attached with holding more cash.

According to Pecking order theory the first and foremost preference of the corporations to finance their investments is given to retained earnings, and then debt and finally at the end they go for equity share. When the corporations have enough funds from operating activities these funds will be sufficient enough to finance firm's new + NPV investments then the firm will repay the debt first of all and then pileup the cash. But when the situation is other way around cash flows or retained earnings will not be sufficient enough to finance the current investments the firm will use the cash that was hold by the firm or the firm will issue new debt.

The believers of the free cash flow theory state that, corporate managers hold the cash to get the flexibility on the firm's investment decisions by increasing the amount of assets under their control. By holding more amount of cash in the current assets there is no need to raise funds for any investment opportunity and managers have flexibility in decision making and they could invest in investments even if that have negative impact on the shareholders wealth.

\section{Problem Statement}

Level of corporate cash holding is a wide research area in the field of finance and applied corporate policies. There are different determinants that affect the level of cash holdings in corporations. This research work aims to determine the determinants that affect the level of cash holdings. Cash and cash equivalent is important policy matter in the field of modern corporate finance that is why this research work is intended to provide solution to the corporate managers regarding accessing cash and liquid assets requirement.

*Author (Abbas Ali) is lecturer at University of Gujrat 


\section{Hypothesis Statement}

Null Hypothesis $(\mathbf{H o})=$ There is no significant impact of leverage, EBIT, total assets (size), MTBV, and capital expenditure on the level of corporate cash holdings.

Alternate Hypothesis (H1) = There is a significant impact of leverage, EBIT, total assets (size), MTBV, and capital expenditure on the level of corporate cash holdings.

\section{Literature Review}

There is a lot of literature available that investigates the determinants of corporate cash holdings. The empirical researches find out the fact that the firm specific factors affecting the corporate cash holdings have different relationships across different countries and firm sizes. Moreover the behaviour of these variables has been changing over time. Recent literature on corporate cash holdings highlights two major motives that explain why firms hold cash. They are the transaction costs motive and the precautionary motive. The transaction costs motive emphasizes that the costs associated with raising external finance deter firms from raising them frequently and thus tend to hold more cash as a safety buffer. On the other hand, the precautionary motive deals with the opportunity costs of positive investments fore gone information asymmetries and agency costs. High adverse selection costs and the costs of financial distress encourage firms to hold more cash to avoid shortfalls in liquidity necessary for financing their investments.

Kim et al. (1998) develop a model for the determinants of cash they find that cash varies positively with the degree of cash flow volatility and growth opportunities, and cash varies inversely with leverage, probability of bankruptcy, and operating performance. Considering the agency costs that arise due to holding excessive cash, Harford (1999) empirically studied the notion that the excessive cash leads the managers to make value decreasing investment decisions. He estimated a sample of all acquisition attempts by US firms during the period of 1977 to 1993 . The results support the hypothesis that acquisition by cash rich firms are value decreasing.

In General, the benefits of corporate cash holdings levels derive from two essential motives, as explained by Opler et al. (1999). One is transaction motive and another is precautionary motive of holding cash. The first one suggests that corporations hold cash to avoid transaction costs of raising funds and to avoid having in other forms of current and less liquid assets Ferreira and Vilela (2004). The precautionary motive refers to the stockpiling of cash as a buffer against difficult circumstances, when capital markets may not be an appealing source of funding for growth Myers and Majluf (1984). This motive pushes smaller firms, firms with riskier cash flows, and firms with significant opportunities for investment and growth to hold more cash. However, holding liquid assets requires firms to pay a liquidity premium: the lower rate of return generated by these held assets. When firms choose to hold low-return liquid assets, they incur opportunity costs, especially by forgoing profitable investments Ferreira and Vilela (2004).

Opler et al. (1999) developed a model by using 1084 US publically traded firms from 1971 to 1994. They found that cash holdings are negatively related to leverage, net working capital, firm size, dividend payment and Govt. regulations and positively related to cash flow to asset ratio. They also found that the firms with better growth opportunities and riskier cash flows had higher level of cash while large firms having better access to market hold less cash. Similar results were reported by Faulkender (2002) for small US firms and Ozkan (2002) for sample of UK firms.

\subsection{Data Selection}

\section{Data and Methodology}

To empirically test hypothesis, the data was gathered from DataStream Live for firms listed in the Germany. A sample of 876 public limited companies listed in German market was taken. The data for over a period of eleven years from 2000 to 2010 inclusive was collected. As on August 2011 by access through DataStream live, in German stock exchange there were 2,841 listed companies. In the first step 724 financial sector and unclassified companies were excluded. From remaining 2,117 companies again by excluding companies with insufficient and repetitive data for studies only 876 companies were considered. The financial sector firms were excluded from the sample because the cash requirements for firms in financial sector are fairly different from the non-financial firms. There balance sheet is entirely different from non-financial firms. The independent variables that are taken to evaluate the cash holdings of the firms in the research are in accordance to the literature on the determinants of corporate cash holding and it includes log of total assets, EBIT, capital expenditure percentage of sales, current ratio as measure of liquidity, and leverage. It is attempted to test the hypothesis stating that corporate cash holdings are influenced by the independent (explanatory) variables. The regression model to test the hypothesis is as follows:

CASH i,t $=\mathrm{a}+\mathrm{b} 1$ LTAi, $\mathrm{t}+\mathrm{b} 2$ EBITi, $\mathrm{t}+\mathrm{b} 3$ Liquidityi, $\mathrm{t}+\mathrm{bLeveragei,t}+\mathrm{b}$ MMTBVi, $\mathrm{t}+\mathrm{b} 6 \mathrm{CAPEXPi,t}+\mathrm{et}$ 
To analyse the variables in the sample, the panel regression model using STATA statistical package is used. The potential heteroscedasticity is controlled and it is assumed that all assumptions of the OLS are not violated in other words these are intact.

\subsection{Data Description \\ 1.2.1 Definition of Independent Variables}

\begin{tabular}{lll}
\hline Tabel 1. Definition of independent variables & Explanation & Finance Theory \\
\hline Name of Variable & Cash/Total assets & - \\
Cash \& cash Equivalent & Natural logarithm of the total assets & - \\
Log of total assets & EBIT/Total Assets & Agency Theory \\
EBIT & Capital expenditures are expressed as a percentage & Pecking order theory \\
Capital Expenditures & of sales & \\
& Percentage of total debt to total assets & Pecking order theory \\
Leverage & Market value of the ordinary share divided by the & Pecking order theory \\
MTBV & balance sheet value of the equity share (common) in & \\
& the company. & \\
\hline
\end{tabular}

\subsubsection{Size}

Size is another significant variable that affects cash holdings. The traditional models to determine the optimal cash levels Baumol (1952), and Miller and Orr, (1966), or more recent models such as that of Mulligan (1997), demonstrate that there are economies of scale associated with the cash levels required to confront the normal transactions of the firm, so that larger firms can keep lower cash holdings.

Moreover, one should also bear in mind that firm size is related to another set of factors that may influence liquidity levels. More specifically, smaller firms suffer more severe information asymmetries Jordan et al. (1998); and Berger et al. (2001), more financial constraints Whited (1992); Fazzari and Petersen (1993). They are more likely to suffer financial distress Rajan and Zingales (1995); and Titman and Issel (1988). Also, financial distress is associated with high fixed costs and these costs are proportionately greater for smaller firms Warner (1977). Thus, one would expect a negative relation between firm size and cash holdings.

\subsubsection{Leverage}

The leverage ratio will also affect a firm's cash holdings. The empirical evidence Kim et al. (1998), Opler et al., (1999); Ferreira and Vilela, (2004); and Ozkan and Ozkan, (2004) demonstrates a reduction in cash levels when firms increase their financial leverage.

This may be because the costs of the funds used to invest in liquid assets rise as financial leverage raises Baskin (1987). In addition, as John (1993) maintains, firms that can access the debt market can resort to borrowing as a substitute for liquid assets.

\subsubsection{Liquidity}

The presence of liquid assets apart from cash and marketable securities for example, debtors or stocks can also affect a firm's optimal cash holdings, since they can be considered substitutes for cash. One would therefore expect firms with more non-cash liquid assets to reduce their cash levels.

\subsubsection{Growth Opportunities}

The existence of growth opportunities in firms is an important factor that positively affects cash levels, as has been shown in various empirical studies Kim et al. (1998); Opler et al. (1999); Ferreira and Vilela (2004); and Ozkan and Ozkan (2004). As Myers and Majluf (1984) point out, firms whose value is largely determined by their growth opportunities have larger information asymmetry. Consequently, firms with greater growth opportunities incur higher external financing costs. They also suffer more serious agency conflicts associated with debt, which can lead to underinvestment insofar as it discourages shareholders from embarking on profitable projects Myers (1977).

Hence one might expect firms with more investment opportunities to keep higher liquidity levels, in order not to limit or cancel their profitable investment projects. The value of the firms is dependent upon them carrying out these projects, thus the cost of not having sufficient cash to make the investments is higher.

\begin{tabular}{lrrrrr}
\hline \multicolumn{2}{l}{ Tabel 2. Summary Statistics } & & & & \\
\hline Variable & \multicolumn{1}{l}{ Obs } & \multicolumn{1}{l}{ Mean } & \multicolumn{1}{c}{ Std. Dev. } & \multicolumn{1}{c}{ Min } & Max \\
Ebit & 8416 & 0.0785999 & 0.3935605 & -12.8333 & 22.1739 \\
Inta & 8416 & 12.22598 & 2.679178 & 0 & 19.38468
\end{tabular}


Determinants of Cash holding in German Market

\begin{tabular}{lrrrrr} 
Cashequa $\neg$ t & 8416 & 0.1388564 & 0.1667551 & 0 & 1 \\
Currentratio & 8211 & 2.74125 & 8.986161 & 0 & 282.85 \\
Leverage & 8342 & 27.51166 & 141.3186 & 0 & 6271.15 \\
MTBV & 6812 & 594.5992 & 48838.83 & -158.91 & 4030907 \\
CE & 7810 & 47.7409 & 1841.902 & -7.41 & 101829.6 \\
\hline
\end{tabular}

Summary statistics shows the mean, high, low value and standard deviation of the variables and provide a general overview of the characteristics of the data. The mean cash ratio over the sample is $13.88 \%$ which is considerably large for nonfinancial firms. These statistics are very close to the US firms' mean cash ratio of $17 \%$ as reported by Opler et al (1999) and the European firms' mean cash ratio of $14.8 \%$ as reported by Ferreira and Vilela (2004). The overall mean market-to-book ratio is 594.60

This table represents a high level of investment opportunities for German firms in comparison to European and American firms who have market-to-book ratio of 1.71 and 1.53 respectively. Mean value of leverage is $27 \%$ which again suggests that Germans firms have a tendency to use more amount of debt to finance their assets as compared to their counterparts in developed countries $(26.1 \%$ in US firms and 24.8 in EMU countries).

\begin{tabular}{lccccccc}
\hline Tabel 3. Correlation Matrix & \multicolumn{1}{c}{ Cash } & Current & Leverage & Mtbv & CE \\
Ebit & Ebit & Inta & & & & & \\
Inta & 1 & & & & & & \\
Cash & 0.1807 & 1 & & & & & \\
Current & -0.0766 & -0.2574 & 1 & & & \\
Leve & -0.0054 & -0.1264 & 0.2929 & 1 & & \\
Mtbv & -0.1217 & 0.0655 & -0.324 & -0.1282 & 1 & \\
CE & 0.0054 & -0.0201 & -0.0079 & -0.0032 & 0.0189 & 1 & \\
\hline
\end{tabular}

The correlation matrix in Table 3 represents the coefficient of correlation of the variables used in the model. Pearson correlation matrix clearly depicts all the explanatory variables, are not highly correlated which is the confirmation of the no multicollinearity problem. The maximum correlation is found in cash and leverage or total debt percentage of total assets. The results of the correlation are significantly different from zero at $1 \%$ level. The sign in the correlation matrix coefficient is a further confirmation of our expectations of the relationship of firms' cash holdings to the explanatory variables. A view at the correlation matrix reveals that of all the explanatory variables, liquidity and leverage are highly correlated with the correlation coefficient of .29 and -0.32 respectively.

\section{Results and Discussion}

The table 4 present the pooled results for the determinants of cash holdings. The value of $\mathrm{R} 2$ and adjusted R2 0.2185 and 0.2177 with $\mathrm{p}$ value for $\mathrm{F}$ statistics represent that the model is fairly fitted well statistically and the VIF (variance inflation factor) indicate no evidence of multicollinearity with mean VIF of 1.03. The results in table 4 shows that the cash holdings is negatively correlated to the size of firm (LTA), retained earnings (in conformity with the pecking order theory ), working capital and leverage at $1 \%$ significant level (highly significant). On the other hand percentage of insider ownership has negative relation with the cash holdings which is not significant any level $(10 \%, 5 \%, 1 \%)$. The result shows the positive relationship with cash flow, dividend pay-out, EBIT, capital expenditures and MTBV which is proxy for the growth opportunities. Expectedly, it was found the leverage to be negatively related to cash holdings. This result is consistent with Ferreira and Vilela (2003) and Ozkan and Ozkan (2004). With the langrage multiplier chi square value of 6.58 (See Appendix) and corresponding $\mathrm{p}$ value of .0103, the null hypothesis is rejected that pool is better than random affect model. Thus the random affect model is considered.

The coefficient of dividend payment shows a positive relationship with cash holding. The result is in line with Ozkan and Ozkan (2004). It suggests that German firms that pays out dividend to their investors tend to hold more cash than those who do not pay dividend. Interestingly, a significant positive relationship between growth opportunities (MTBV) and cash holdings was found. This represents that firms in Germany use large amount of internally generated cash to finance positive net present value projects in other words this means that firms with high growth opportunities hold more cash to avail opportunities available. Consistent with the findings from previous studies, the results demonstrate cash holdings to decrease with the level of liquid assets (Working Capital). 


\begin{tabular}{lccc}
\hline Tabel 4. Comparison of results & & & \\
\hline & Pooled Effect & Random Effect & Fixed Effect \\
EBIT & -0.05356 & 0.009055 & 0.021349 \\
& $(-6.55)^{*}$ & $(1.44)$ & $(3.37)^{*}$ \\
LNTA & -0.01346 & -0.01641 & -0.0162 \\
& $(-16.55)^{*}$ & $(-10.44)^{*}$ & $(-5.47)^{*}$ \\
Current & .0047401 & .0024288 & .0020284 \\
Leverage & $(20.08)^{*}$ & $(13.83)^{*}$ & $(11.57)^{*}$ \\
MTBV & -0.00198 & -0.00093 & -0.0067 \\
& $(-25.20)^{*}$ & $(-12.61)^{*}$ & $(-8.83)^{*}$ \\
CE & -.00024 & -.0000063 & -.00000195 \\
$\mathbf{R}^{2}$ & $(-0.46)$ & $(-0.17)$ & $(-0.05)$ \\
Number of Groups & 0.000158 & .0000515 & .0000228 \\
Number of Observations & $(2.15)^{* *}$ & $(0.96)$ & $(0.43)$ \\
Hausman & 0.2185 & .1860 & .1668 \\
Test & 712 & 712 & 712 \\
\hline
\end{tabular}

The table present pooled effect, random effect and fixed effect respectively, predicting determinants of corporate cash holdings. The test statistics are in parentheses. ${ }^{*}, * *$ and $* * *$ denote significant at $1 \%, 5 \%$ and $10 \%$ levels respectively.

The Hausman's test was used to verify if random effect would be a better model to use. Hausman test gives 129.59 with a $\mathrm{p}$ value of 0.0000 which is less than 0.5 . So the null will be rejected and fixed effect is better will be accepted.

The results in Table 4 present the panel regression estimations for cash and cash equivalent. Table 4 present the results and it is clear that the value of $\mathrm{R} 2$ and adjusted $\mathrm{R}^{2}$ is appreciable 0.2286 and 0.2221 with pooled regression respectively for cash and significant at $1 \%$ levels with $F$ statistics of 35.55 and $p$ value 0.0000 (See Table 4). This confirm that firms pursue a target cash holdings level after due consideration to the determinants.

It is found that market-to-book ratio coefficient is significant at $1 \%$ level, consistent with free cash flow theory that states that managers with poor investment opportunities (low market-to-book ratio) hold more cash to ensure availability of funds for investment in growth projects which may earn a negative NPV. This result suggests the agency problem is prevalent in German firms, where managers try to avoid raising external funds for keeping the investment information of the company to themselves.

Firm size, cash flow and industry sigma are significant at $1 \%$ level in the cross sectional regression analysis. The positive coefficient on cash flow-to-assets ratio supports the pecking order theory which suggests that firms finance investments first with the retained earnings and then go for debt. This result is, however, in contradiction to trade off model as reported by the earlier researches for firms in developed countries, i.e. Opler et al. (1999) Ozkan and Ozkan (2002) and Ferreira and Vilela (2004). The reason for this incongruity may be high cost of external debt in Germany.

The sign on industry sigma is positive and significant which is in conformity with the expectations and empirical research. It suggests that firms with greater cash flow volatility hold more cash in order to provide a safe cushion for smooth operations.

The results support the notion that firms with higher leverage hold less cash, which is consistent with pecking order and free cash flow theories. As per the pecking order theory, when firms' investments are in excess of retained earnings, high levels of debt and little cash holdings occur simultaneously. This negative relationship is also supported by free cash flow theory but the main reason is because high leverage firms are subject to monitoring by capital markets preventing superior managerial control.

The negative sign on net working capital is consistent with the notion that firms with higher liquid assets substitutes hold less cash which is consistent with the expected relationship between the two variables.

\section{Conclusion}

The aim of this work was to examine the determinants of the cash holdings in non-financial firm. Taking this in consideration, a sample of 876 German firms was used to conduct a study with panel data. This panel was made up of 6130 observations corresponding to 876 firms during the period 2000-2010 both years inclusive.

Initially pooled regression model was used and the findings were in confirmation with the available literature on cash holding. These results showed that the cash holdings are negatively correlated to the size of firm (LTA), market to book value and leverage. In addition to this it is important to note that with Lagrange 
Multiplier Test, it was found that random affect is best representation of the model. On comparison of the random affect model it was found that results are not too much different from the pooled regression with cash flow and insider ownership change significantly under random effect model. The most significant economic impact was for the presences of the substitutes for cash in the balance sheet of the corporation under current assets. This exerted a negative effect on firm's cash holdings like it can be seen as working capital negatively related to the level of cash holding, since possessing liquid assets reduces cash levels. On the other hand, substantial empirical support for the influence of leverage on levels of cash was found.

\section{References}

[1]. Guney, Y., Ozkan, A. and Ozkan, N. (2003): “Additional International Evidence on Corporate Cash Holding”. EFMA Helsinki meetings.

[2]. Ferreira, M. A. and Vilela, A. S. (2004): "Why do firms hold cash? Evidence from EMU countries", European Financial Management 10, 295-319.

[3]. Pinkowitz, L. and Williamson, R. (2001) "Bank Power and Cash Holdings: Evidence from Japan", Review of Financial Studies, Vol. 4, pp. 1059-1082.

[4]. Opler, T., Pinkowitz, L., Stulz, R. and Williamson, R. (1999) “The Determinants and Implications of Corporate Cash Holdings", Journal of Financial Economics, Vol. 52, pp.3-46.

[5]. Ozkan, A. and Ozkan, N., (2002) “Corporate Cash Holdings: An Empirical Investigation of UK Companies', Working Paper University of York.

[6]. Harford, J. (1999) “Corporate Cash Reserves and Acquisitions” Journal of Finance, Vol.54, pp. 1969-1997.

[7]. Dittmar, A., Mahrt-Smith, J. and Servaes, H. (2003) "International Corporate Governance and Corporate Cash Holdings", Journal of Financial and Quantitative Analysis, Vol. 28, pp. 111-133.

[8]. Ferreira, Miguel A. and Vilela, Antonio S. (2004) "Why Do Firms Hold Cash? Evidence from EMU Countries" European Financial Management Vol. 10 No.pp. 295-319.

[9]. Drobetz, W. and Grüninger M. (2006) "Corporate Cash Holdings: Evidence from a Different Institutional Setting" presented at 9th SGF conference.

[10]. Faulkender, M. (2002) "Cash Holdings among Small Business", Working Paper (Kellogg School of Management, Northistern University).

[11]. Campbell, T. and Brendsel, L. (1977) "The impact of compensating Balance Requirements on the Cash Balances of Manufacturing Corporations: An Empirical Study" The Journal of Finance Vol. 32 pp. 31-40.

[12]. Ferreira, M.A., Vilela, A.S., (2004). Why do firms hold cash? Evidence from EMU countries. European Financial Management 10(2), 295-319.

[13]. Myers, S.C., Majluf, N.S., (1984). Corporate financing and investment decisions when firm have information that investors do not have. Journal of Financial Economics 13 (2), 187-221.

[14]. Pinkowitz, L. and Williamson, R. (2001), "Bank Power and cash holdings: evidence from Japan", Review of Financial Studies, vol. 14 no 4: pp. 1059- 1082.

[15]. Pinkowitz, L., Stulz, R. M. and Williamson, R. (2004), "Do firms in countries with poor protection of investor rights hold more cash? ", NBER working paper.

[16]. Sargan, J. D. (1958), "The estimation of economic relationships using instrumental variables", Econometric a, vol. 26: p. 393-415.

[17]. Schnure, C. (1998), "Who holds cash? And why?", Federal Reserve Board Working Paper 98-13.

[18]. John, T.A. (1993): "Accounting measures of corporate liquidity, leverage, and costs of financial distress", Financial Management 22, 91-100.

[19]. Myers, S. (1977): "Determinants of corporate borrowing”, Journal of Financial Economics 5, 147-175.

[20]. Ozkan, A. and Ozkan, N. (2004): "Corporate cash holdings: An empirical investigation of UK companies", Journal of Banking and Finance 2, 2103-2134.

[21]. Kim,C., Mauer, D., Sherman,A., (1998). The determinants of corporate liquidity: theory and evidence. Journal of Financial and Quantitative Analysis 33(3), 335-359.

[22]. Titman, S., Wessels, R., (1988). The determinants of capital structure choice. The Journal of Finance 43 (1), 1-19.

[23]. Pinkowitz, L., Williamson, R., (2001). Bank power and cash holdings: evidence from Japan. Review of Financial Studies 14 (4), 1059-1082.

[24]. Williamson, O., (1988). Corporate finance and corporate governance. The Journal of Finance 43 (3), $567-591$.

[25]. John, T. A. (1993), "Accounting measures of corporate liquidity, leverage, and costs of financial distress", Financial Management, vol. 22: pp. 91-100.

[26]. La Porta, R., Lopez De Silanes, F., Shleifer, A. and Vishny, R. W. (1997), "Legal determinants of external finance", Journal of Finance, vol. 52 no 3: pp. 1131-1150.

[27]. La Porta, R., Lopez De Silanes, F., Shleifer, A. and Vishny, R. W. (1998), "Law and finance”, Journal of Political Economy, vol. 106 no 6: pp. 1113-1155.

[28]. Pinkowitz, L. (2002), "The market for corporate control and corporate cash holdings", working paper, Georgetown University.

Appendix

\begin{tabular}{lrr}
\hline Tabel 5. Variance Inflation Factor & \multicolumn{3}{c}{ 1/VIF } \\
\hline Variable & VIF & \multicolumn{2}{c}{} \\
Inta & 1.06 & 0.944771 \\
Ebit & 1.05 & 0.948719 \\
Leverage & 1.04 & 0.962403 \\
Currentratio & 1.03 & 0.969563 \\
Ce & 1 & 0.997797
\end{tabular}




\begin{tabular}{lrrr}
\hline Tabel 6. Hausman Test & \multicolumn{2}{c}{ Random } & Difference \\
\hline & \multicolumn{1}{c}{ Fixed } & 0.0090549 & 0.0122944 \\
Ebit & 0.0213493 & -0.016406 & 0.0002017 \\
Inta & -0.0162042 & 0.0024288 & -0.0004004 \\
Currentratio & 0.0020284 & -0.000926 & 0.0002518 \\
Leverage & -0.0006741 & -0.000926 & $4.41 \mathrm{E}-06$ \\
Mtbv & $-1.95 \mathrm{E}-06$ & 0.0000515 & -0.0000287 \\
CE & 0.0000228 & & \\
\hline
\end{tabular}

Hausman test is the test that evaluates the significance of an estimator versus another estimator? Hausman test gives vales of 126.59 and $\mathrm{P}$ value of $\mathbf{0 . 0 0 0 0}$ which is less than 05 . So fixed is better because if p-value is less than 0.5 , then the fixed effects model should be used.

\begin{tabular}{|c|c|c|}
\hline Variable & DS Code & Details \\
\hline Market to book value & MTBV & $\begin{array}{l}\text { Market value of equity share divided by the balance sheet value } \\
\text { in the company. }\end{array}$ \\
\hline Leverage & 08236 & $\begin{array}{l}\text { Short Term Debt \& Current Portion of Long Term Debt + Long } \\
\text { Term Debt) / Total Assets * } 100\end{array}$ \\
\hline Funds flow from operation & 04201 & $\begin{array}{l}\text { Funds flow from operation represents the sum of net income and } \\
\text { all non-cash charges or credits. It is the cash flow of the } \\
\text { company. }\end{array}$ \\
\hline Total Assets & 02999 & \\
\hline $\begin{array}{l}\text { Cash \& short term } \\
\text { investments }\end{array}$ & 02001 & $\begin{array}{l}\text { Cash \& short term investment represents the sum of cash and } \\
\text { short Term investments }\end{array}$ \\
\hline Return on Equity & DWRE & (EBIT/equity)*100 \\
\hline $\begin{array}{l}\text { Capital expenditures } \% \\
\text { sales }\end{array}$ & 08421 & Capital Expenditures / Net Sales or Revenues * 100 \\
\hline
\end{tabular}

\begin{tabular}{|c|c|c|c|c|c|c|}
\hline \multirow{2}{*}{\multicolumn{2}{|c|}{$\begin{array}{l}\text { R-Sq: within }=.0498 \\
\text { between }=.2623 \\
\text { Overall }=.1860\end{array}$}} & & & \multicolumn{3}{|c|}{$\begin{array}{l}\text { wald chi2 }(6)=529.40 \\
\text { prob }>\text { chi } 2=.0000\end{array}$} \\
\hline & & & & & & \\
\hline Cashequiv & Cofe. & \multirow{2}{*}{$\begin{array}{r}\text { Std. Err. } \\
0.006288\end{array}$} & \multirow{2}{*}{$\frac{\mathbf{Z}}{1.44}$} & \multirow{2}{*}{$\frac{\mathbf{p}>/ \mathbf{z} /}{0.15}$} & \multicolumn{2}{|c|}{$95 \%$ conf. interval } \\
\hline Ebit & 0.009055 & & & & -0.00327 & $.0213 \mathrm{t} 793$ \\
\hline Inta & -0.01641 & 0.001553 & -10.57 & 0 & -0.01945 & -0.01336 \\
\hline Currentra & $2.43 \mathrm{E}-03$ & $1.76 \mathrm{E}-04$ & 13.83 & 0 & $2.08 \mathrm{E}-03$ & 0.002773 \\
\hline Leverage & -0.00093 & 7.34E-05 & -12.61 & 0 & -0.00107 & -0.00078 \\
\hline MTBV & $-6.35 \mathrm{E}-06$ & 3.67E-05 & -0.17 & 0.863 & $-7.8 \mathrm{E}-05$ & $6.56 \mathrm{E}-05$ \\
\hline $\mathbf{C E}$ & $5.15 \mathrm{E}-05$ & $5.36 \mathrm{E}-05$ & 0.96 & 0.336 & $-5.3 \mathrm{E}-05$ & 0.000157 \\
\hline Cons & $3.54 \mathrm{E}-01$ & 0.019253 & 18.4 & 0 & 0.316598 & 0.392067 \\
\hline
\end{tabular}

